Western North American Naturalist 71(4), (C) 2011, pp. 442-455

\title{
STATUS OF LOST RIVER SUCKER AND SHORTNOSE SUCKER
}

\author{
Josh E. Rasmussen
}

\begin{abstract}
The endangered Lost River sucker (Deltistes luxatus) and shortnose sucker (Chasmistes brevirostris) are endemic to the Upper Klamath Basin, Oregon and California. The once very abundant populations have declined drastically due to a combination of habitat loss and impairment, disruption of reproduction and gene flow, intensive harvest, and loss of entire populations. Spawning populations within Upper Klamath Lake are declining and have not had significant recruitment for over a decade. In addition to habitat loss, these populations are threatened by periodic harmful water conditions resulting from massive algal blooms and entrainment of larvae and juveniles into water delivery systems or hydroelectric structures. Populations of shortnose sucker in Clear Lake appear to be relatively healthy and stable, but recruitment of Lost River sucker appears to be sparse. These populations are affected by drought and water management. Other populations are potentially introgressed with Klamath largescale sucker (Catostomus snyderi) or lack sufficient spawning opportunities to be self-sustaining and therefore function as sink populations. Although genetic and ecological similarities between the species are strong, it is important to better understand the needs of both species individually to assure effectiveness and efficiency in recovery efforts. Determination of the factors limiting juvenile survival and recruitment is vital and should be part of a broader program which includes comparison among populations to understand demography and vital rates. Efforts should also include habitat restoration, improvement of water quality conditions, and reduction of entrainment, as well as monitoring to evaluate effectiveness. Lastly, a controlled propagation program should be considered and/or implemented to conserve unique genetic stocks and provide opportunity for augmentation of wild-spawned populations.
\end{abstract}

RESUMEn.-Las especies en peligro de extinción Lost River sucker (Deltistes luxatus) y shortnose sucker (Chasmistes brevirostris) son endémicas de la parte alta de la cuenca Klamath en Oregón y California. Las poblaciones que alguna vez fueron muy abundantes han disminuido drásticamente debido a una combinación de pérdida y degradación de los hábitats, interrupción de la reproducción y del flujo de genes, pesca intensiva y pérdida de poblaciones enteras. Las poblaciones que desovan dentro del Lago Upper Klamath están disminuyendo y no han tenido un reclutamiento significativo por más de una década. Además de la pérdida del hábitat, estas poblaciones se ven amenazadas por condiciones periódicas de aguas nocivas que son el resultado de la proliferación desmedida de algas y por el arrastre de larvas y jóvenes a los sistemas de suministro de agua o estructuras hidroeléctricas. Las poblaciones de Chasmistes brevirostris en el Lago Clear parecen estar relativamente saludables y estables, pero el reclutamiento de Deltistes luxatus parece ser escaso. La sequía y el manejo de las aguas afectan estas poblaciones. Es posible que otras poblaciones experimenten introgresión con el Klamath largescale sucker (Catostomus snyderi) o que carezcan de suficientes oportunidades para desovar y así poder sostenerse por sí mismos, por lo que consecuentemente funcionan como poblaciones sumidero. A pesar de que las similitudes genéticas y ecológicas entre las especies son grandes, es importante entender mejor las necesidades individuales de ambas especies para asegurar la eficacia y eficiencia en los esfuerzos por recuperarlas. La determinación de los factores que limitan la supervivencia y el reclutamiento de jóvenes es vital y debería ser parte de un programa más extenso para entender la demografía y las tasas vitales, incluyendo las comparaciones entre las poblaciones. Estos esfuerzos también deben incluir la restauración del hábitat, el aumento en la calidad del agua y la disminución del arrastre, así como su monitoreo para evaluar su eficacia. Por último, debe considerarse y/o implementarse un programa de propagación controlada para conservar las reservas genéticas únicas y brindar oportunidad para el aumento de poblaciones que desovan en su ambiente natural.

In general, nonsport fish species of the western United States have received little attention relative to sport fish or species that are from more populous areas (Cooke et al. 2005). Abundances of many of these species have declined, often unnoticed, to levels that warrant protection under the Endangered Species Act (Riccardi and Rasmussen 1999). Even though these species may receive support from and protection of legislative efforts, recovery is often severely hampered by a lack of basic biological information (Belk and Johnson 2007). Successful recovery of imperiled species is dependent on understanding and protecting the ecological and genetic diversity within the species, as well as on minimizing threats (Boersma et al. 2001). The process of recovery or conservation of any imperiled species involves an often complex interaction of scientific, social, and political forces (Ruckelshaus et al. 2002) from which

${ }^{1}$ Klamath Falls Fish and Wildlife Office, 1936 California Ave., Klamath Falls, OR 97601. E-mail: josh_rasmussen@fws.gov 
policy-driven actions arise. The role of science within this process is to provide pertinent biological information on status and threats to the species and criteria needed to determine success of recovery efforts (Ruckelshaus et al. 2002). Because of the limited information on many imperiled species, recovery actions are often generalized to broader taxonomic levels (i.e., extrapolating the known ecology of species related at the genus or even family level to the species of interest) or to ecological groups (e.g., lake-dwelling or long-lived; Wilcove and Master 2005). This approach yields inefficient and potentially ineffective recovery efforts. Boersma et al. (2001) concluded that species included in multispecies or ecosystem-based recovery plans were 4 times more likely to continue declining than species covered under singlespecies plans. Additionally, recovery efforts often occur in discrete segments of species (e.g., populations, stocks, age classes), with little emphasis on synthesis of information to inform the broader picture of species-level recovery.

It is necessary to periodically assess the pertinence of existing biological information and to identify gaps within the data. A general framework for doing so includes assessing the current status of and threats to the species and identifying the most fertile areas for future study (Ruckelshaus et al. 2002, Belk and Johnson 2007). Here I examine the status of and threats to 2 endangered western suckers and recommend areas of future emphasis for science.

Lost River sucker (Deltistes luxatus) and shortnose sucker (Chasmistes brevirostris) are 2 lake-dwelling species with a range restricted to the Upper Klamath Basin (Fig. 1) located in south central Oregon and northern California. Gilbert (1897) and Evermann and Meek (1897) described 2 additional species from Upper Klamath Lake, Chasmistes stomias and Chasmistes copei, neither of which are known to occur in the system presently. It is unclear whether these descriptions represent true species that have apparently been extirpated or forms of the existing species (hybrids, ecotypes, or morphotypes) that have become uncommon (Moyle 2002).

Lost River sucker and shortnose sucker share many similar ecological and life history traits. Both are long-lived, iteroparous, relatively largebodied, and highly fecund species (Markle and Cooperman 2002, Terwilliger et al. 2010). Both species are essentially obligate lake-dwellers as adults but also utilize fluvial, littoral, and limnetic habitats in the basin at some point during the life cycle (e.g., spawning and rearing), and both exhibit apparent adaptations (terminal to subterminal mouths) for zooplanktivory (Miller and Smith 1981, Cooke et al. 2005). Some differences do exist (such as morphology, spawning behavior, and larval habitat preferences), but perhaps because of the preponderance of similarities, including strongly overlapping ranges, and because they were listed together as endangered, these 2 species are often treated together. In large part, the similarities are emphasized and the differences are poorly acknowledged, leading to generalized recovery efforts which may fail to address the entire spectrum of diversity within each of the species.

\section{STATUS}

Lost River sucker and shortnose sucker were once extremely abundant, providing significant support for indigenous cultures prior to European settlement (Cope 1879, Speir 1930, Stern 1965). Bendire (1889) describes an annual capturing and drying spectacle that occurred during springtime spawning runs up the Lost River. Similarly, a large recreational fishery centered on the species well into the 20th century (Markle and Cooperman 2002). However, by the late 1960s, declines in overall catch and average size of individual fish were documented by the Oregon Department of Fish and Wildlife, which considers the species to be a game fish (Markle and Cooperman 2002). Unfortunately, it is impossible to accurately quantify the magnitude of these declines, because even broad estimates were lacking until very recently (Markle and Cooperman 2002); however, it is generally accepted that these species were both extremely abundant but now only occur in much lower numbers. The continued declines eventually prompted concurrent federal listing in 1988 of both species as endangered under the Federal Endangered Species Act (USFWS 1988), which also triggered an endangered listing by the state of Oregon. Both species had been previously listed by the state of California in 1974 (California Department of Fish and Game 2010).

The distributions of these species are well defined, but demographic, ecological, or genetic information is lacking in many respects. In 


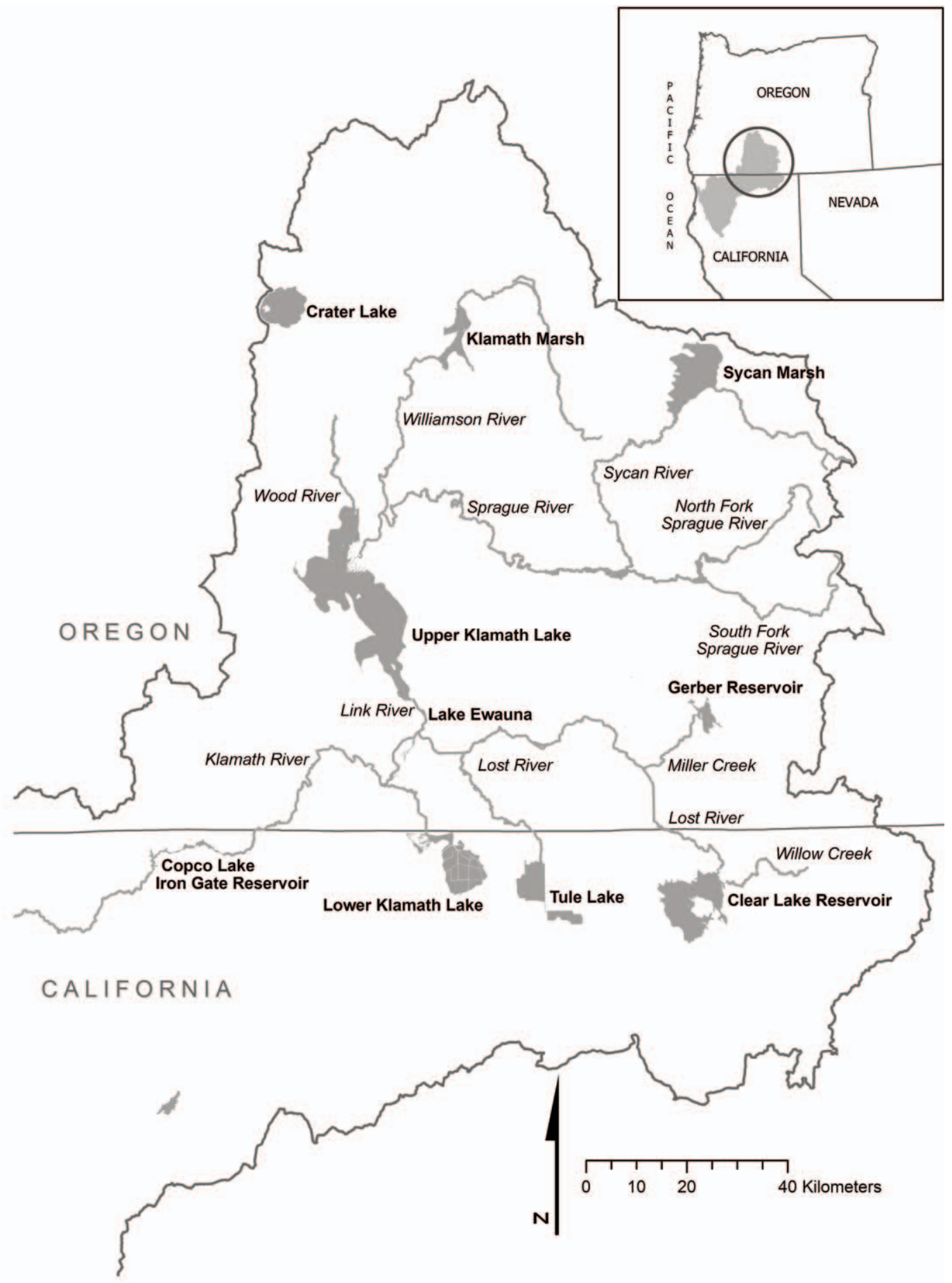

Fig. 1. Distributional range of Lost River sucker (Deltistes luxatus) and shortnose sucker (Chasmistes brevirostris) in the upper Klamath Basin, Oregon and California. Populations of suckers occur in Upper Klamath Lake, Clear Lake, Tule Lake, Gerber Reservoir, and reservoirs along the main stem of Klamath River and Lost River. Populations of suckers also occurred historically in Lower Klamath Lake and Lake of the Woods (a small lake approximately $16 \mathrm{~km}$ west of Upper Klamath Lake). 
many instances, research focuses on periods in the life cycle or populations that are easier to sample, such as spawning congregations. However, this approach of opportunistically focusing on inherently more detectable portions of populations may lead to a situation where management decisions are influenced more by the relative ease with which some data can be collected rather than by more important biological needs of the species. Such research may produce strong data on spawners and/or larvae but limited data on juveniles or nonreproductive adults, and these limitations may ultimately have important implications for the effectiveness of recovery efforts. For example, Crouse et al. (1987) determined that efforts to save imperiled loggerhead sea turtles (Caretta caretta) were focused on the life stage that was the least responsive (eggs) to population recovery and that efforts should be refocused on a more responsive stage (juveniles). Similar conclusions were drawn by Kinney and Simpfendorfer (2009) concerning the relative importance of nursery habitat for sharks in juvenile life stages. While limited data can be useful and better than no data at all, an incomplete understanding of the ecology and status of species will always pose challenges and create inefficiencies for recovery.

\section{Distributional Status}

Prior to European settlement, Lost River sucker and shortnose sucker occurred in approximately 4-5 lakes in the Upper Klamath Basin of south central Oregon and northern California, including the Lost River subbasin (Fig. 1). The upper basin is formed by the Cascade Range to the west and high desert basin and range systems to the east, and it drains to the Pacific Ocean in northern California. Water bodies with major populations historically included Upper Klamath Lake, Lake Ewauna, Lower Klamath Lake, Tule Lake, and Clear Lake. The latter 2 are located in the Lost River subbasin. A population of suckers described as shortnose sucker (NRC 2004), or Chasmistes stomias (Andreasen 1975), also occurred until 1952 in Lake of the Woods, located approximately $16 \mathrm{~km}$ west of Upper Klamath Lake.

Upper Klamath Lake is a relatively large but shallow freshwater lake at approximately $1263 \mathrm{~m}$ above sea level (Fig. 2). Prior to 1960, surface area of the lake was between 31,600 and 44,900 ha, but since that time surface area has been managed to between 22,700 and 27,100 ha (NRC 2004). Depths can reach up to $18 \mathrm{~m}$ in some trenches along the western shores, but average depth is $2.7 \mathrm{~m}$, which translates into a volume of approximately 630,000 acre-feet (NRC 2004). The primary tributaries to Upper Klamath Lake are the Williamson River, which receives the Sprague River shortly before feeding into Upper Klamath Lake, and the Wood River (Cummings 2007). Together the Williamson and Sprague rivers account for $79 \%$ of the total area that drains into Upper Klamath Lake (Risley et al. 2005). Groundwater is an important component of Upper Klamath Lake hydrology (Gannett et al. 2007). Many biologically important springs or seeps enter directly into the lake proper, namely, Harriman Springs, Barkley Spring, and a series of small springs along the eastern shoreline of the lake. Upper Klamath Lake drains through a short outlet known as Link River. Historically a natural reef influenced lake levels, but this reef was lowered in places and Link River Dam (completed in 1921) was placed downstream to allow for management of lake levels for irrigation purposes (NRC 2004). The Link River flows a short distance (approximately $2 \mathrm{~km}$ ) before emptying into Lake Ewauna. When Keno Dam was placed downstream, this second natural lake was altered and expanded due to its merger with the Keno Impoundment.

Within the Lost River subbasin, Clear Lake receives water from Willow Creek and subsequently gives rise to the Lost River, which runs in an arching loop to the north before turning south to empty into Tule Lake. Clear Lake (elevation $1366 \mathrm{~m}$ ) is again a natural system that was altered (expanded and deepened) by the placement of a dam (completed in 1910; BOR 2000). This lake remains relatively shallow (average depth $6.1 \mathrm{~m}$ ) and broad (surface area up to approximately 10,400 ha; NRC 2004), which results in a high evaporation rate. Specific mention of the historical presence of sucker in this lake is lacking, but their presence is probable, given the high abundance of sucker downstream in Tule Lake.

Tule Lake and Lower Klamath Lake are very similar in many respects. These lakes were large, shallow bodies of water with areas of emergent aquatic vegetation. A ridge separated the 2 lakes historically, but a small canal now carries water pumped from Tule Lake into Lower Klamath Lake, providing limited hydrologic connectivity. 


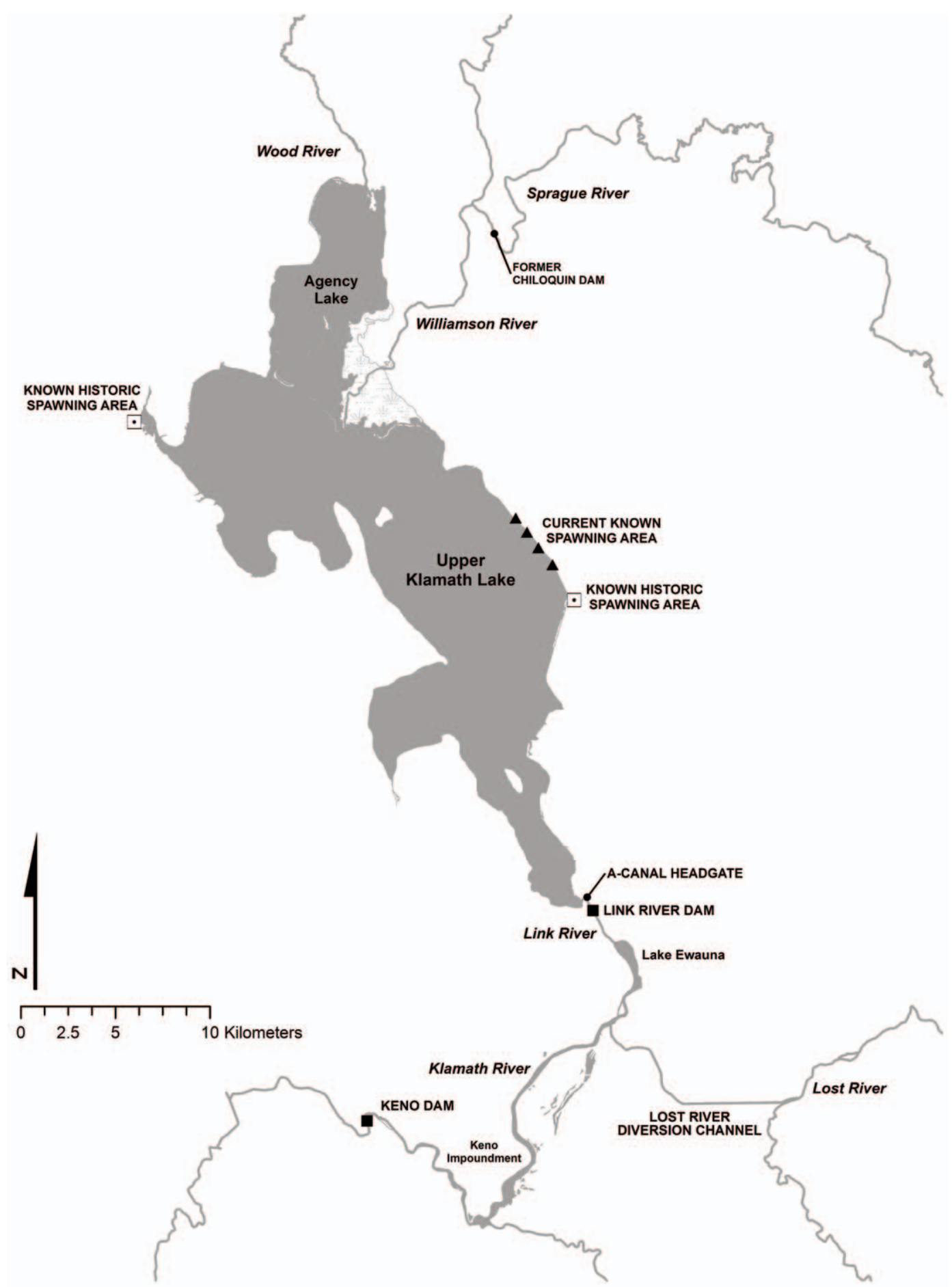

Fig. 2. Areas important to sucker biology in Upper Klamath Lake, Oregon. Spring sites of major known and historic populations within Upper Klamath Lake are identified with symbols. Area identified as wetland habitat indicates shallow areas of the restored delta of the Williamson River. 
High flows in Klamath River resulting from spring runoff historically provided connectivity between Upper Klamath Lake and these lakes, but probably more so to Lower Klamath Lake, which could maintain a relatively strong connection with Klamath River and Lake Ewauna during wet periods (Gilbert 1897). However, beginning in the 1930s, significant portions of both Tule Lake and Lower Klamath Lake were drained to provide area for agriculture, despite much of the area having been designated National Wildlife Refuges to provide waterfowl habitat (NRC 2004). The lakes currently receive relatively little hydrologic input. Much of Tule Lake's main tributary, the Lost River, is diverted for irrigation, and the Klamath River has been levied to prevent flooding into the area previously occupied by Lower Klamath Lake and surrounding wetlands.

Individuals of both species of sucker are known to persist in Upper Klamath Lake, Lake Ewauna, Clear Lake, and Tule Lake (USFWS 1988). However, the overall ranges of most of these populations have been severely reduced or isolated. No documentation of suckers within Lower Klamath Lake has occurred in decades (Buettner and Scoppettone 1991), but sampling has been very limited. The overall distributional range of the species has been expanded elsewhere by creation of reservoirs. The Klamath River has seen the addition of several other downstream dams (J.C. Boyle, Copco 1 and 2, and Iron Gate dams), which create impoundments that are at least marginally suitable for sucker survival, but not for reproduction. Gerber Reservoir (created in 1914) on Miller Creek supports a presumably reproducing population of putative shortnose sucker (BOR 2000, NRC 2004). However, because dams and diversion structures throughout the system obstruct upstream movement of spawning or dispersing adults, populations in Tule Lake and Klamath River impoundments function as sink populations in which adults are able to survive but no evidence of significant reproduction has been documented.

\section{Demography}

Spawning populations of Lake River sucker and shortnose sucker within Upper Klamath Lake are currently declining (Janney et al. 2008). Between 1999 and 2008, approximately 25,000 Lost River sucker were captured and tagged during surveys of the spawning populations in
Upper Klamath Lake. Approximately 10,000 were associated with the river-spawning life history and the remainder with the springspawning life history (Janney et al. 2009). Close to 14,000 shortnose sucker, which predominantly exhibit the river-spawning life history, were captured and tagged in Upper Klamath Lake between 1995 and 2008 (Janney et al. 2009). From these spawning populations, large numbers of larvae are hatched each year (Cooperman and Markle 2003, 2004, Cooperman et al. 2010, Ellsworth et al. 2010), and age-0 juveniles can be found until late summer, when they become very scarce (Bottcher and Burdick 2010, Burdick and Vanderkooi 2010). Recruitment to the spawning populations has been negligible for the past 10-12 years (Markle and Cooperman 2002, Janney et al. 2008). Length-frequency data suggest that the last significant recruitment to the adult population in Upper Klamath Lake occurred in the late-1990s from fish that were spawned earlier in that decade (Janney et al. 2008). Consequently, spawning populations consist of a relatively homogenous size distribution strongly skewed toward large individuals, which is interpreted to mean that the age distribution is also relatively homogenous. Terwilliger et al. (2010) concluded from ages determined from hard structures (e.g., otoliths and opercles) that the age distribution of present populations in Upper Klamath Lake has been truncated relative to the few instances of historical (1970 and 1986) data available.

For both species, sex ratios for captures in the Williamson and Sprague rivers between 2000 (shortnose sucker) or 2001 (Lost River sucker) and 2008 were skewed toward females, with the ratio of males per female for Lost River sucker $(0.72)$ on average being slightly higher than that for shortnose sucker $(0.57$; data from Janney et al. 2009). However, these ratios declined for both species during this period. Sex ratios of trammel-net captures of Lost River sucker associated with the eastern shoreline springs (19992008) also steadily declined over time, from 4.72 males per female in 1999 to 0.91 in 2008, with a median ratio of 1.82 (data from Janney et al. 2009). Males consistently exhibit higher mortality rates than females (Janney et al. 2008), which can explain much of this declining trend in sex ratios, but the ultimate causes of this disparity in mortality rates is unknown.

Within Clear Lake, combined captures of both species approach 10,000 individuals since 
2006 (Barry et al. 2009). Shortnose sucker within Clear Lake appear to have had relatively regular recruitment to the adult population, but the Lost River sucker populations appear to exhibit the same progression toward increasing lengths, which is indicative of low levels of additions to the spawning population (D. Hewitt, USGS, personal communication 2011). Sex ratios (males to females) from physical captures periodically obtained from 1993 through 2008 are similar to those of Upper Klamath Lake populations. Ratios for Lost River sucker are slightly higher than those for shortnose sucker (medians are 0.99 and 0.58 , respectively), and a declining trend is apparent, although significant gaps within the data limit comparisons (Barry et al. 2009). Between 2006 and 2008, remote passive integrated transponder (PIT) tag detections of individuals entering Willow Creek for spawning suggest important differences between the species. Sex ratios for Lost River sucker ranged from 1.28 to 3.36 , while ratios for shortnose sucker ranged from 0.38 to 0.43 (Barry et al. 2009). It is unclear if the apparent disparity in recruitment between the species is related to these differences in sex ratios.

Since most other populations function as sinks, the only other population with significant spawning is found in Gerber Reservoir (putative shortnose sucker only). This population persists, but no data exists concerning its demography.

\section{Ecological Status}

Limited ecological variation has been noted between Lost River sucker and shortnose sucker, and as a result these 2 species are often lumped together when conservation needs and recovery actions are addressed. However, important diversity among and within populations of the species exists. In general, shortnose sucker are slightly smaller with a more terminal mouth, while Lost River sucker possess a longer snout and a relatively more ventral mouth, although still subterminal. Differences are also evident in the diets of adults. Shortnose sucker consume a higher amount of small organisms relative to detritus, while the opposite is true for Lost River sucker. The common occurrence of detritus within the gut of adult shortnose sucker suggests that its feeding is still closely associated with the benthos.

Spawning behavior is very similar, with both species exhibiting a river-spawning and a spring-spawning life history, except that the spring-spawning component is much stronger for Lost River sucker (approximately 30\%; Perkins et al. 2000b, Janney et al. 2009). Both species ascend the Williamson and Sprague rivers to spawn, from late February (shortnose sucker) and late March (Lost River sucker) until late May, while temperatures are at least $10^{\circ} \mathrm{C}$ (Janney et al. 2009). Shoreline spring spawning is also known to occur between February and May at 4 primary sites (Cinder Flat, Ouxy Spring, Silver Building Spring, and Sucker Spring) along the eastern shoreline of Upper Klamath Lake (Janney et al. 2009). Upon swim-up, larvae in the river quickly drift downstream and utilize vegetated, littoral habitats (Coleman et al. 1987, Cooperman and Markle 2003, Ellsworth et al. 2009). The fate and disposition of larvae spawned at the springs is unknown. Successful larval production appears to be dependent on at least 3 factors: presence of emergent macrophytes, air temperature, and a lack of strong wind events (Cooperman et al. 2010). Larvae feed within the water column until approximately $25 \mathrm{~mm}$ standard length, when they transition to a benthic diet (Markle and Clauson 2006). Adult Lost River sucker appear to inhabit slightly deeper habitats than adult shortnose sucker. Banish et al. (2009) found that based on 50\% kernel estimates, radio-tagged Lost River sucker were often associated with relatively deeper areas (e.g., immediately off of Ball Point and Eagle Ridge Point), whereas shortnose sucker tended to be more often associated with areas relatively near the shoreline.

Populations in Clear Lake appear to exhibit slightly different ecology in some respects. Growth of individuals is higher in Clear Lake than in Upper Klamath Lake, between 2 and 4 times higher in some instances (Barry et al. 2009). The reason for this disparity is unknown and unexpected, especially since Clear Lake's relatively high turbidity results in less productivity than occurs in the less turbid Upper Klamath Lake; but this may reflect growth rates of a younger population. Populations in Clear Lake also spawn at an earlier date than those in Upper Klamath Lake (Barry et al. 2009), which is potentially an adaptation to the relatively small drainage that feeds Willow Creek, making the system very sensitive to drought or variation in the hydrograph.

For most other populations, data are again notably limited. There have been reports of limited fluvial populations in the Sprague River 
near Beatty Gap and in the main tributary to Clear Lake (Willow Creek); however, data concerning any ecological differences between these populations and their lake-dwelling counterparts is absent.

\section{Genetic Status}

The restricted geographical range and the likelihood of genetic exchange among populations, and to a lesser extent among subbasins, suggests that genetic differentiation is unlikely to be very high. Although the species are morphologically and meristically distinct and exhibit intraspecific variation geographically (Markle et al. 2005), physical traits often suggest introgression (Miller and Smith 1981, Wagman 2003, Markle et al. 2005), especially between shortnose sucker and Klamath largescale sucker $(\mathrm{Ca}$ tostomus snyderi). Temporal and/or spatial criteria are often used to distinguish these 2 taxa (Markle et al. 2005).

The limited reports assessing genetic diversity suggest evidence for introgression and hybridization among shortnose sucker and Klamath largescale sucker (Tranah 2001, Wagman 2003, Tranah and May 2006). Microsatellite data reveal intraspecific divergence of these 2 species between basins but not interspecific divergence within basins (Tranah and May 2006). Mitochondrial DNA research indicates similar patterns of introgression and hybridization between shortnose sucker and Klamath largescale sucker (Dowling 2005). This research also identifies a low level of introgression between Lost River sucker and either shortnose sucker, Klamath largescale sucker, or both. Of Lost River suckers surveyed, $2 \%$ possessed haplotypes common to the other species. In contrast, $12 \%$ of the shortnose sucker analyzed possessed haplotypes common to Lost River sucker. The historical patterns and significance of such introgression require further investigation (Hubbs 1955, Dowling and Secor 1997).

Within Gerber Reservoir reside populations of putative shortnose sucker and Klamath largescale sucker which especially possess morphological and genetic traits intermediate to both species. The provenance of this population is unknown, given that the reservoir was created in 1925 on a stream that "ran dry from June to October in most years" (BOR 2000:12). Populations here either arose from established streamdwelling individuals or were introduced at some point. Further investigations of this system may provide insight into the evolutionary relationship of shortnose sucker and Klamath largescale sucker. It is unknown whether rates of hybridization between these species differ from historical rates, and if so, how such changes may affect the evolutionary legacy of the species (Rhymer and Simberloff 1996).

Lost River sucker are readily distinguished morphologically and genetically from shortnose sucker and Klamath largescale sucker and exhibit low intraspecific divergence between the Lost River and the Klamath River subbasins (Dowling 2005, Tranah and May 2006). There is no detectable genetic distinction between river-spawning and shoreline spring-spawning subpopulations, but the site fidelity is very strong (i.e., straying between spawning locations is extremely rare; Janney et al. 2009).

\section{Threats}

In general, the most notable threats to the species' continued existence are the drastic declines in abundance, reduction of species resistance and resiliency due to loss of entire populations or subpopulations, limited connectivity among remaining populations, and inability of several populations to produce successful recruitment. For example, populations or subpopulations at Harriman Springs and Barkley Springs and within the Wood River Drainage, Lake of the Woods, and Lower Klamath Lake have been entirely extirpated. Much of the connectivity among populations is "one-way," with individuals being able to move (either by entrainment or volitionally) to the lower parts of the system but having their return upstream movement blocked. Such conditions expose the species to the risk of extinction, as there are fewer individuals to weather detrimental events and the species lack the ability to replenish upstream populations when needed.

These threats result from the existence and interaction of diverse factors, including habitat loss, impaired water quality, entrainment into water diversion, and hydroelectric structures. In addition to these better-researched threats, a myriad of other biological threats-such as disease (e.g., Flavobacterium columnare or gillrot disease), predators (native lamprey and salmonids, as well as avian), and introduced species (namely, fathead minnow [Pimephales promelas]; Markle and Dunsmoor 2007)—also potentially negatively affect the species; however, 
little is known of the relative or absolute effects of these factors. For example, an algal hepatotoxin known to affect fish (Malbrouck and Kestemont 2006) occurs in Upper Klamath Lake and has been implicated in liver damage of juvenile suckers (Vanderkooi et al. 2010). It is largely unknown whether current conditions are indicative of historical impacts or whether effects have become exacerbated or reduced due to water conditions and habitat alterations. Nevertheless, given the drastic reduction in population size and the lack of recruitment, even impacts reflective of historical conditions have the potential to be magnified.

\section{Habitat Loss}

Habitat loss can be absolute (reduction in the physical extent of previously suitable areas) or functional (degradation, separation, or alteration of habitat effectually limiting the services previously provided by these areas). Both absolute and functional loss of habitat are common in this system (NRC 2004). Although not all of the historical wetland habitat may have been used directly by suckers, other areas often provide ecological services important in the dynamics of water quality and water quantity, and thus may indirectly affect the species. Approximately 55,000 ha ( $~ 50 \%$ at the time) of lake and wetland habitat (or areas that influenced habitat) were lost when portions of Tule Lake and Lower Klamath Lake were converted to agricultural use. Along the eastern shore of Upper Klamath Lake, spawning and rearing habitat have been reduced significantly because of construction of a railroad, with much of the remaining area significantly impacted by associated boulder riprap. Quantitative estimates of the extent of this habitat loss are impossible, but current habitat along the eastern shoreline is approximately only 0.25 ha.

Water management structures (dams and diversions) are common throughout the system (BOR 2000). By 1925, six major dams had been constructed to serve the Klamath Project, including Link River Dam, Gerber Dam, Clear Lake Dam, Wilson Diversion Dam, Malone Diversion Dam, and Anderson Rose Dam (BOR 2000). By enabling management of the system, water management structures often create an unnatural hydrology. Such conditions may alter habitat which may directly affect suckers or may limit the species' ability to adapt to increased competition or predation by introduced species (Simon and Markle 1997, Markle and Dunsmoor 2007). Water management structures also reduce upstream connectivity throughout the system and expedite habitat reduction by diverting water for extensive irrigation. Chiloquin Dam, a nonproject dam completed in 1914, restricted access to approximately $120 \mathrm{~km}$ of spawning habitat and migration corridor.

In addition to these structures, the channelization of rivers and streams alters hydrologic functioning and stream characteristics, such as residence time. Habitat alteration also results from agriculture and grazing, which affect riparian areas along rivers that serve as spawning habitat. Such alterations can affect the biological (e.g., allocthonous inputs), chemical or physical (e.g., nutrient or temperature loading), and geomorphological (e.g., pool-riffle ratios and sediment loading) functioning of rivers (Armour et al. 1994, Rasmussen 2002).

\section{Water Quality}

Water quality is another factor contributing to the functional loss of habitat, most notably within Upper Klamath Lake (NRC 2004, Morace 2007, Hoilman et al. 2008). Algal communities have shifted within the past 100 years to a near monoculture of the blue-green alga Aphanizomenon flos-aquae (Eilers et al. 2004), which has the ability to fix atmospheric nitrogen and regulate its own buoyancy (NRC 2004). Although the exact mechanisms by which this alga came to dominant the system are debated (NRC 2004), the combination of alga ecology and high phosphorus load within the system from internal sediment loads and external (i.e., agricultural) inputs (Kuwabara et al. 2007) lead to massive algal blooms. Resultant crashes and decomposition severely deplete dissolved oxygen levels in the water and are likely a culprit in the considerable die-offs of fish in the lake, such as those that occurred in 1996 and 1997 (Martin and Saiki 1999, Saiki et al. 1999, Perkins et al. 2000a, Hoilman et al. 2008). Low dissolved oxygen, in conjunction with elevated temperatures $\left(>22{ }^{\circ} \mathrm{C}\right)$, is also associated with reduced larval growth (Terwilliger et al. 2003). Abundances of Aphanizomenon flos-aquae also produce relatively high $\mathrm{pH}$ and high levels of unionized ammonia at levels that can be toxic to suckers in the laboratory (Lease 2000, Wood et al. 2006); however, variation of these parameters was not related to natural die-offs (Martin and Saiki 1999). 


\section{Entrainment}

Lastly, entrainment of larvae and juveniles is a major source of loss to the populations. Many small diversions exist throughout the Sprague and Williamson rivers and around Upper Klamath Lake, but the 2 primary points for entrainment within Upper Klamath Lake are the A-canal and Link River Dam. Predominant northwesterly winds drive a current, or gyre, within Upper Klamath Lake that flows in a clockwise direction (Wood et al. 2006). Larvae and young juveniles unable to sufficiently resist the force of the current are entrained in the flow and swept toward the southern area of the lake and into close proximity of the major outflows (Reithel 2006, Markle et al. 2009). This entrainment certainly occurred historically, but it is probable that littoral wetlands that have since been altered or lost provided locations that could retain many individuals, preventing many from washing downstream (Markle et al. 2009). Whether losses due to entrainment are compensatory (i.e., individuals would experience mortality whether entrained or not) or additive to natural mortality is currently unknown. For example, all species, including juvenile sucker, sampled within the Link River during summer 2009 had high incidence of parasitic infection but few clinical signs of disease, a possible indication that weakened individuals were being entrained (Foott et al. 2010). Losses additive to natural mortality would represent a significant impact to the species.

The A-canal is a primary source for the vast network of canals that serve the U.S. Bureau of Reclamation Klamath Project (BOR 2000). Individuals entrained into this system remain within the canals until end-of-the-year salvage efforts or are lost by further entrainment onto agricultural fields or when drawdown occurs. Recent efforts to reduce entrainment into the A-canal include a fish screen that is engineered to redirect individuals $>30 \mathrm{~mm}$ in length back into Upper Klamath Lake. Prior to screening, an estimated 50,000 (1997) to over 200,000 young-of-the-year suckers were entrained into the A-canal (Gutermuth et al. 2000a). With this relatively new structure, entrainment into the A-canal is significantly reduced, but the overall effects to the fish are yet unclear. For example, it is unclear whether the bypassed fish remain in the Upper Klamath Lake or if they are re-entrained in the A-canal or Link River Dam.
There are several points at Link River Dam where fish can be entrained, 2 of which enter hydroelectric facilities, while the others pass directly into Link River. Gutermuth et al. (2000b) estimated entrainment of approximately 110,000 suckers (primarily young-of-the-year) into the hydroelectric facilities of Link River Dam between 1997 and 1999. To reduce this effect, cessation of operation during critical periods has been adopted. Nevertheless, individuals can still pass directly into Link River through the gates of the dam. Individuals surviving entrainment through the Link River Dam must then be reared within Link River or the unfavorable habitat of Keno Impoundment. Link River Dam is the only dam with a fish ladder accessible to suckers for upstream passage; detection of suckers using the ladder to pass upstream into Upper Klamath Lake has been limited but appears to be increasing (T. Tyler, Bureau of Reclamation, personal communication 2010).

\section{ReCOvery}

Though not entirely obvious, the story of Lost River sucker and shortnose sucker is somewhat of a success story. The life history and ecology of these species has enabled them to persist despite the dramatic loss or impairment of significant portions of habitat, disruption of reproduction and gene flow, intensive harvest, and even loss of entire populations. Nonetheless, these species still have a high risk of extinction, given that populations with fewer individuals are in general less resilient to perturbation (Shaffer 1981, O'Grady et al. 2004). Likewise, as the number of populations (or unique subpopulations) declines or as populations continue to exist without connectivity, genetic variability and adaptability may also decline and the risk of extinction increases. O'Grady et al. (2004) determined that population trend was the best predictor of extinction risk, especially for relatively large populations. Given the significant declining trend in spawning population size (E. Janney and D. Hewitt, USGS, unpublished data), these species are truly endangered.

Efforts to minimize threats and reduce this risk of extinction have recently achieved several significant improvements to habitat. Approximately, 2200 ha of wetland and riparian habitat by the delta at the mouth of the Williamson River were restored through cooperative efforts 
of The Nature Conservancy, Natural Resources Conservation Service, U.S Bureau of Reclamation, U.S. Fish and Wildlife Service, PacifiCorp, National Fish and Wildlife Foundation, Oregon Watershed Enhancement Board, and The Klamath Tribes (Crandall et al. 2008, TNC 2009). Likewise, even though passage at the Chiloquin Dam on the Sprague River was possible (Janney et al. 2009), it is believed that removal of this dam (2008) will ease the access of spawners to the $78 \mathrm{~km}$ of spawning habitat upstream and increase the out-migration of larvae and juveniles (Ellsworth et al. 2009, 2010). Screening of the A-canal intake (2002), as well as screening of a major diversion point along the southwestern shore of Upper Klamath Lake (Geary Canal; 2009), should significantly reduce the entrainment of juveniles over $30 \mathrm{~mm}$.

Notwithstanding the similarities of these species in both ecology and threats, it is important that recovery efforts be focused on each species separately to (1) continue clarification of basic evolutionary and ecological trajectories of each species and (2) address management practices, such as improving water quality or reducing entrainment, that will most effectively lessen the impacts of threats. To accomplish this objective, research and recovery actions should be implemented for population-level units nested within subbasin-level units for each species. This research should include clarification of population dynamics and vital rates for each life stage within populations, including those populations that appear to be reproducing and stable. Most importantly, research should examine the factors affecting the juvenile stage within Upper Klamath Lake and the apparent lack of recruitment to the spawning population.

It is also very important that coordinated synthesis of research be conducted regularly. Given the various entities and organizations involved in the recovery of the 2 sucker species, it is important to gather and combine information from all populations to better understand the needs of the species. For example, clarification of vital rates within Clear Lake populations may provide insight into the limiting factors in Upper Klamath Lake. As efforts proceed, the effectiveness and outcomes of actions, individually and collectively, must be assessed. For example, as connectivity among populations is restored, it will be imperative to understand the developing patterns of metapopulation dynamics, including immigration, emigration, and gene flow.
Notwithstanding the amount of valid information on Lost River sucker and shortnose sucker, much remains uncertain. Thus, management policy should include a mixture of available approaches, and all potential means should be explored and utilized if deemed appropriate (Belk and Johnson 2007), such as the use of modeling scenarios, including population dynamic matrices, for assessment of potential outcomes to actions (Ruckelshaus et al. 2002). Given the declining trend of spawning population numbers within Upper Klamath Lake, it may also be necessary to initiate a controlled propagation program to conserve unique genetic stocks and diversity, as well as to provide the opportunity for artificial augmentation, as part of the process. However, given the concerns associated with such programs (Ryman and Laikre 1991, Belk et al. 2008, Rasmussen et al. 2009), planning and preparation should be undertaken to minimize negative consequences.

\section{ACKNOWLEDGMENTS}

I thank E. Billman, B.J. Brush, and N. Rasmussen for providing valuable comments and assistance during manuscript preparation. I have also benefitted greatly from insight gained through discussions on this topic with R. Larson.

\section{Literature Cited}

Andreasen, J.K. 1975. Systematics and status of the family Catostomidae in southern Oregon. Oregon State University, Corvallis, OR.

Armour, C., D. Duff, And W. Elmore. 1994. The effects of livestock grazing on western riparian and stream ecosystem. Fisheries 19:9-12.

Banish, N.P., B.J. Adams, R.S. Shively, M.M. Mazur, D.A. Beauchamp, and T.M. Wood. 2009. Distribution and habitat associations of radio-tagged adult Lost River suckers and shortnose suckers in Upper Klamath Lake, Oregon. Transactions of the American Fisheries Society 138:153-168.

Barky, P.M., E.C. Janney, D.A. Hewitt, B.S. Hayes, and A.C. SCOTT. 2009. Population dynamics of adult Lost River (Deltistes luxatus) and shortnose (Chasmistes brevirostris) suckers in Clear Lake, California, 20062008: Open File Report 2009-1109, U.S. Geological Survey, Reston, VA.

Belk, M.C., L.J. Benson, J. Rasmussen, and S.L. Peck. 2008. Hatchery-induced morphological variation in an endangered fish: a challenge for hatchery-based recovery efforts. Canadian Journal of Fisheries and Aquatic Sciences 65:401-408.

BELK, M.C., AND J.B. Johnson. 2007. Biological status of leatherside chub: a framework for conservation of western freshwater fishes. Pages 67-76 in M.J. Brouder 
and J.A. Scheurer, editors, Status, distribution, and conservation of native freshwater fishes of western North America. American Fisheries Society, Bethesda, MD.

Bendire, C.E. 1889. The Lost River sucker. Forest and Stream 32:444-445.

Boersma, P.D., P. Kareiva, W.F. Fagan, J.A. Clark, and J.M. Hoekstra. 2001. How good are endangered species recovery plans? BioScience 51:643-649.

Bottcher, J.L., AND S.M. Burdick. 2010. Temporal and spatial distribution of endangered juvenile Lost River and shortnose suckers in relation to environmental variables in Upper Klamath Lake, Oregon: 2009 annual data summary. Open File Report 2010-1261, U.S Geological Survey, Reston, VA.

Buettner, M., and G. SCoppettone. 1991. Distribution and information on the taxonomic status of shortnose sucker, Chasmistes brevirostris, and Lost River sucker, Deltistes luxatus, in the Klamath River Basin, California. Reno Substation, Seattle National Fisheries Research Center, U.S. Fish and Wildlife Service, U.S. Department of Interior, Reno, NV.

Burdick, S.M., and S.P. VANDERKOOI. 2010. Temporal and spatial distribution of endangered juvenile Lost River and shortnose suckers in relation to environmental variables in Upper Klamath Lake, Oregon, 2008 annual data survey. Open File Report 2010-1051, U.S. Geological Survey, Reston, VA.

[BOR] Bureau of Reclamation. 2000. Klamath Project historic operation. Klamath Basin Area Office, Bureau of Reclamation, U.S. Department of the Interior, Klamath Falls, OR.

California Department of Fish and Game. 2010. State and federally listed endangered and threatened animals of California. Natural Resources Agency, State of California, Sacramento, CA.

Coleman, M.E., A.M. McGie, And D.L. BotTom. 1987. Evaluate causes for the decline of the shortnose and Lost River suckers in Klamath Lake, Oregon. Fish Division, Oregon Department of Fish and Wildlife, Portland, OR.

Cooke, S.J., C.M. Bunt, S.J. Hamilton, C.A. Jennings, M.P. Pearson, M.S. CoOperman, and D.F. Markle. 2005. Threats, conservation strategies, and prognosis for suckers (Catostomidae) in North America: insights from regional case studies of a diverse family of nongame fishes. Biological Conservation 121:317-331.

Cooperman, M.S., AND D.F. MarkLE. 2003. Rapid outmigration of Lost River and shortnose sucker larvae from in-river spawning beds to in-lake rearing grounds. Transactions of the American Fisheries Society 132: $1138-1153$

2004. Abundance, size, and feeding success of larval shortnose suckers and Lost River suckers from different habitats of the littoral zone of Upper Klamath Lake. Environmental Biology of Fishes 71:365-377.

Cooperman, M.S., D.F. Markle, M. Terwilliger, and D.C. SimON. 2010. A production estimate approach to analyze habitat and weather effects on recruitment of two endangered freshwater fish. Canadian Journal of Fisheries and Aquatic Sciences 67:28-41.

Cope, E.D. 1879. Fishes of Klamath Lake, Oregon. American Naturalist 13:784-785.

Crandall, J.D., L.B. Bach, N. Rudd, M. Stern, and M. BARRY. 2008. Response of larval Lost River and shortnose suckers to wetland restoration at the Williamson River Delta, Oregon. Transactions of the American Fisheries Society 137:402-416.
Crouse, D.T., L.B. Crowder, and H. Caswell. 1987. A stage-based population model for loggerhead sea turtles and implications for conservation. Ecology 68:1412-1423.

Cummings, M.L. 2007. Hydrogeology of the Williamson River basin, Upper Klamath Basin, Klamath County, Oregon. Portland State University, Portland, OR.

DowLING, T.E. 2005. Conservation genetics of endangered Lost River and shortnose suckers. Unpublished report, Arizona State University, Tempe, AZ.

Dowling, T.E., And C.L. Secor. 1997. The role of hybridization and introgression in the diversification of animals. Annual Review of Ecology and Systematics 28:593-619.

Eilers, J.M., J. Kann, J. Cornett, K. Moser, and A. St. Amand. 2004. Paleolimnological evidence of change in a shallow, hypereutrophic lake: Upper Klamath Lake, Oregon. Hydrobiologia 520:7-18.

Ellsworth, C.M., T.J. Tyler, and S.P. Vanderkooi. 2010. Using spatial, seasonal, and diel drift patterns of larval Lost River suckers Deltistes luxatus (Cypriniformes: Catostomidae) and shortnose suckers Chasmistes brevirostris (Cypriniformes: Catostomidae) to help identify a site for a water withdrawl structure on the Williamson River, Oregon. Environmental Biology of Fishes 89:47-57.

Ellsworth, C.M., T.J. Tyler, S.P. Vanderkooi, and D.F. MarkLE. 2009. Patterns of larval sucker emigration from the Sprague and Lower Williamson Rivers of the Upper Klamath Basin, Oregon, prior to removal of Chiloquin Dam-2006 annual report. Open File Report 2009-1027, U.S. Geological Survey, Reston, VA.

Evermann, B.W., AND S.E. Meek. 1897. A report upon salmon investigations in the Columbia River Basin and elsewhere on the Pacific Coast in 1896. Bulletin of the United States Fish Commission 17:15-84.

Foott, J.S., R. Stone, and R. Fogerty. 2010. FY2009 technical report: health and energy evaluation of juvenile fish from Link R. trap and haul project and J-canal salvage. California Nevada Fish Health Center, U.S. Fish and Wildlife Service, Anderson, CA.

GannetT, M.W., K.E. Lite JR., J.L. La Marche, B.J. Fisher, AND D.J. PoletTE. 2007. Groundwater hydrology of the upper Klamath Basin, Oregon and California. Scientific Investigations Report 2007-5050. U.S. Geological Survey, Reston, VA.

GilberT, C.H. 1897. The fishes of the Klamath Basin. Bulletin of the United States Fish Commission 17:1-13.

Gutermuth, B., E. Pinkston, And D. Vogel. 2000a. A-canal fish entrainment during 1997 and 1998 with emphasis on endangered suckers. New Earth/Cell Tech, Klamath Falls, OR, and Natural Resource Scientists, Inc., Red Bluff, CA.

Gutermuth, B., C. Watson, And J. Kelly. 2000b. Link River hydroelectric project (east and westside powerhouses) final entrainment study report. Cell Tech, Klamath Falls, OR, and PacificCorp Environmental Services, Portland, OR.

Hoilman, G.R., M.K. Lindenberg, and T.M. Wood. 2008. Water quality conditions in Upper Klamath and Agency Lakes, Oregon 2005. Scientific Investigations Report 2008-5026, U.S. Geological Survey, Reston, VA.

HubBs, C.L. 1955. Hybridization between fish species in nature. Systematic Zoology 4:1-20.

Janney, E.C., B.S. Hayes, D.A. Hewitt, P.M. Barry, A. SCOTT, J. Koller, M. Johnson, and G. BlackWOOD. 
2009. Demographics and 2008 run timing of adult Lost River (Deltistes luxatus) and shortnose (Chasmistes brevirostris) suckers in Upper Klamath Lake, Oregon, 2008. U.S. Geological Survey, Reston, VA.

Janney, E.C., R.S. Shively, B.S. Hayes, P.M. Barky, and D. Perkins. 2008. Demographic analysis of Lost River sucker and shortnose sucker populations in Upper Klamath Lake, Oregon. Transactions of the American Fisheries Society 137:1812-1825.

Kinney, M.J., And C.A. Simpfendorfer. 2009. Reassessing the value of nursery areas to shark conservation and management. Conservation Letters 2:53-60.

Kuwabara, J.S., D.D. Lynch, B.R. Topping, F. Murphy, J.L. Carter, N.S. Simon, F. Parchaso, T.M. Wood, M.K. Lindenberg, K. Wiese, and R.J. Avanzino. 2007. Quantifying the benthic source of nutrients to the water column of Upper Klamath Lake, Oregon. Open File Report 2007-1276, U.S. Geological Survey, Reston, VA.

LEase, H.M. 2000. Histopathological changes in gills of Lost River suckers (Deltistes luxatus) exposed to elevated ammonia and elevated $\mathrm{pH}$. Oregon State University, Corvallis, OR.

Malbrouck, C., and P. Kestemont. 2006. Effects of microcystins on fish. Environmental Toxicology and Chemistry 25:72-86.

Markle, D.F., M.R. Cavalluzzi, and D.C. Simon. 2005. Morphology and taxonomy of Klamath Basin suckers (Catostomidae). Western North American Naturalist 65:473-489.

Markle, D.F., and K. Clauson. 2006. Ontogenetic and habitat-related changes in diet of larval and juvenile suckers (Catostomidae) in Upper Klamath Lake, Oregon. Western North American Naturalist 66:492-501.

MarkLe, D.F., and M.S. Cooperman. 2002. Relationship between Lost River and shortnose sucker biology and management of Upper Klamath Lake. Pages 93-117 in $\mathrm{B}$. Braunworth and $\mathrm{T}$. Welch, editors, Water allocation in the Klamath Reclamation Project, 2001: an assessment of natural resource, economic, social, and institutional issues with a focus on the Upper Klamath Basin. Oregon State University and University of California, Corvallis, OR.

Markle, D.F., and L.K. Dunsmoor. 2007. Effects of habitat volume and fathead minnow introduction on larval survival of two endangered sucker species in Upper Klamath Lake, Oregon. Transactions of the American Fisheries Society 136:567-579.

Markle, D.F., S.A. Reithel, J. Crandall, T.M. Wood, T.J. Tyler, M. Terwilliger, and D.C. Simon. 2009. Larval fish transport and retention and the importance of location for juvenile fish recruitment in Upper Klamath Lake, Oregon. Transactions of the American Fisheries Society 138:328-347.

Martin, B.A., and M.K. SaIKI. 1999. Effects of ambient water quality on the endangered Lost River sucker in Upper Klamath Lake, Oregon. Transactions of the American Fisheries Society 128:953-961.

MilLER, R.R., AND G.R. Smith. 1981. Distribution and evolution of Chasmistes (Pisces: Catostomidae) in western North America. Occasional Papers of the Museum of Zoology, University of Michigan 696:1-48.

Morace, J.L. 2007. Relation between selected water-quality variables, climatic factors, and lake levels in Upper Klamath and Agency Lakes, Oregon, 1990-2006. Scientific Investigations Report 2007-5117, U.S. Geological Survey, Reston, VA.
MoYLe, P.B. 2002. Inland fishes of California. University of California Press, Berkeley, CA.

[NRC] National Research Council. 2004. Endangered and threatened fishes in the Klamath River Basin: cause of decline and strategies for recovery. National Academies Press, Washington, DC.

o'Grady, J.J., D.H. Reed, B.W. Brook, and R. Frankham. 2004. What are the best correlates of predicted extinction risk? Biological Conservation 118:513-520.

Perkins, D.L., J. Kahn, and G.G. Scoppettone. 2000a. The role of poor water quality and fish kills in the decline of endangered Lost River and shortnose suckers in Upper Klamath Lake. Unpublished report, U.S. Geological Survey, Reno, NV.

Perkins, D.L., G.G. Scoppettone, and M. Buettner. 2000b. Reproductive biology and demographics of endangered Lost River and shortnose suckers in Upper Klamath Lake, Oregon. U.S. Geological Survey, Reno.

RASMUSSEN, J.E. 2002. Seasonal responses of water quality and macroinvertebrate communities to riparian fencing in livestock pastures of Whiteley Creek, Pennsylvania. California University of Pennsylvania, California, PA.

Rasmussen, J.E., M.C. BelK, and S.L. Peck. 2009 Endangered species augmentation: a case study of alternative rearing methods. Endangered Species Research 8:225-232

Reithel, S.A. 2006. Patterns of retention and vagrancy in larval Lost River and shortnose suckers from Upper Klamath Lake, Oregon. Oregon State University, Corvallis, OR.

Rhymer, J.M., And D. Simberloff. 1996. Extinction by hybridization and introgression. Annual Review of Ecology and Systematics 27:83-109.

RicCARdi, A., AND J.B. Rasmussen. 1999. Extinction rates of North American freshwater fauna. Conservation Biology 13:1220-1222.

Risley, J.C., M.W. Gannett, J.K. LEA, And E.A. Roehl Jr. 2005. An analysis of statistical methods for seasonal flow forecasting in the upper Klamath Basin of Oregon and California. Scientific Investigations Report 2005-5177, U.S. Geological Survey, Reston, VA.

Ruckelshaus, M.H., P. Levin, J.B. Johnson, and P.M. KAREIVA. 2002. The pacific salmon wars: what science brings to the challenge of recovering species. Annual Review of Ecology and Systematics 33:665-706.

Ryman, N., and L. LaIKre. 1991. Effects of supportive breeding on the genetically effective population size. Conservation Biology 5:325-329.

SaIKI, M.K., D.P. Monda, and B.L. Bellerud. 1999. Lethal levels of selected water quality variables to larval and juvenile Lost River and shortnose suckers. Environmental Pollution 105:37-44.

SHAFFER, M.L. 1981. Minimum population sizes for species conservation. BioScience 31:131-134.

SimON, D.C., AND D.F. MaRKLE. 1997. Interannual abundance of nonnative fathead minnows (Pimephales promelas) in Upper Klamath Lake, Oregon. Western North American Naturalist 57:142-148.

SPEIR, L. 1930. Klamath ethnography. University of California Press, Berkeley, CA.

Stern, T. 1965. The Klamath Tribe: a people and their reservation. University of Washington Press, Seattle, WA.

Terwilliger, M., D.F. MarkLe, and J. Kahn. 2003. Associations between water quality and daily growth of juvenile shortnose and Lost River suckers in Upper Klamath Lake, Oregon. Transactions of the American Fisheries Society 132:691-708. 
Terwilliger, M., T. Reece, and D.F. Markle. 2010. Historic and recent age structure and growth of endangered Lost River and shortnose suckers in Upper Klamath Lake, Oregon. Environmental Biology of Fishes 89:239-252.

[TNC] The Nature Conservancy. 2009. Williamson River Delta Preserve: technical reports 2006-2009. The Nature Conservancy, Portland, OR.

TranaH, G.J. 2001. Molecular genetic analysis of hybridization and population structure in endangered sturgeon and sucker species. University of California, Davis, CA.

Tranah, G.J., And B. May. 2006. Patterns of intra- and interspecies genetic diversity in Klamath River Basin suckers. Transactions of the American Fisheries Society 135:306-316.

[USFWS] United States Fish and Wildlife Service. 1988. Endangered and threatened wildlife and plants: determination of endangered status for the shortnose sucker and Lost River sucker, Final Rule. Federal Register 53(137):27130-27134.
VAnderkooi, S.P. S.M. Burdick, K.R. Echols, C.A OTTINGER, B.H. Rosen, AND T.M. WoOd. 2010. Algal toxins in Upper Klamath Lake, Oregon: linking water quality to juvenile sucker health. Fact-Sheet 20093111, U.S. Geological Survey.

Wagman, D.W. 2003. Species identification of Klamath Basin suckers (Pisces: Catostomidae) and an assessment of hybridization using anonymous nuclear loci. Oregon State University, Corvallis, OR.

Wilcove, D.S., and L.L. Master. 2005. How many endangered species are there in the United States? Frontiers in Ecology and the Environment 3:414-420.

Wood, T.M., G.R. Hollman, and M.K. LindenberG. 2006. Water-quality conditions in Upper Klamath Lake, Oregon, 2002-04. Scientific Investigations Report 2006-5209, U.S. Geological Survey, Reston, VA.

Received 23 November 2010 Accepted 13 June 2011 